\title{
Gastrointestinal Neuroendocrine Tumor Pathologic TNM Finding v7
}

National Cancer Institute

\section{Source}

National Cancer Institute. Gastrointestinal Neuroendocrine Tumor Pathologic TNM

Finding v7. NCI Thesaurus. Code C90065.

A pathologic finding about one or more characteristics of gastrointestinal neuroendocrine tumor, following the rules of the TNM AJCC v7 classification system. The pathologic staging is based on endoscopic biopsy specimens, percutaneous biopsies, fine-needle aspirates, surgical exploration, and on examination of surgically resected primary tumor, lymph nodes, and distant metastases. (from AJCC 7th Ed.) 